\title{
RISIKO USAHATANI PADI PADA WILAYAH BANTARAN SUNGAI CITANDUY (Kasus di Desa Manggungsari, Kecamatan Rajapolah, Kabupaten Tasikmalaya)
}

\author{
RISK FARMING IN THE AREA OF CITANDUY RIVER BANKS \\ (Case in Manggungsari Village, District Rajapolah, Tasikmalaya Regency)
}

\author{
Hendar Nuryaman*, Faqihuddin \\ Jurusan Agribisnis, Fakultas Pertanian, Universitas Siliwangi \\ *E-mail: hendarnuryaman@unsil.ac.id \\ (Diterima 25-02-2020; Disetujui 24-04-2020)
}

\begin{abstract}
ABSTRAK
Bantaran sungai merupakan jalur tanah pada kiri dan kanan sungai, umumnya ditanami dengan tanaman yang akarnya mengikat kuat pada tanah atau juga dengan tanaman musiman seperti padi, begitu juga pada wilayah bantaran sungai citanduy. Risiko merupakan suatu hal yang harus dihadapi siapa saja, kemampuan petani dalam mengelola risiko menarik untuk dipelajari agar dapat menggambarkan risiko apa saja yang dihadapi pada usahatani khususnya padi. Tujuan penelitian ini untuk: 1) Mengidentifikasi macam-macam risiko yang dihadapi petani padi; 2) Menganalisis risiko produksi, biaya dan pendapatan usahatani padi; dan 3) Mengetahui cara petani dalam menghadapi risiko usahatani padi. Penelitian dilakukan pada 31 orang petani padi di Desa Manggungsari, Kecamatan Rajapolah, Kabupaten Tasikmalaya dengan menggunakan Metode survei. Analisis mengggunakan analisis deskriptif dan analisis risiko (Koefisien Variasi/KV). Hasil penelitian menunjukkan bahwa macam-macam risiko yang dihadapi petani pada usahatani padi adalah gangguan organisme pengganggu tanaman (hama, penyakit dan gulma), harga jual gabah/beras yang fluktuatif, lambatnya fasilitas pembangunan (irigasi, jalan, gudang), rusaknya alat-alat produksi akibat penggunaan yang terus menerus, dan sulitnya dalam mencari pinjaman modal usahatani. Analisis risiko menunjukkan bahwa risiko produksi, biaya dan pendapatan dikategorikan rendah. Selanjutnya strategi yang dipilih oleh petani dalam menghadapi risiko sebelum melakukan usahatani padi atau mengalami risiko, petani terlebih dahulu membuat perencanaan bersama kelompok tani dan penyuluh pertanian, pada saat masa produksi apabila memasuki musim kemarau, petani lebih banyak untuk memperbaiki saluran air yang ada karena khawatir lahannya kekeringan dan setelah mengalami risiko, petani tetap melakukan usahataninya disamping mencari pekerjaan lain untuk memperoleh pendapatan tambahan.
\end{abstract}

Kata kunci: Risiko, Usahatani, Padi, Bantaran Sungai

\begin{abstract}
Riverbanks are land lines on the left and right side of the river, generally planted with plants whose roots are firmly bound to the ground or also with seasonal crops such as rice, as well as in the citanduy riverbanks. Risk is something that must be faced by anyone, the ability of farmers to manage risk is interesting to learn in order to describe what risks are faced in farming, especially rice. The purpose of this study is to: 1) Identify the types of risks faced by rice farmers; 2) Analyzing the risks of production, costs and income of rice farming; and, 3) Knowing how farmers deal with the risks of rice farming. The study was conducted on 31 rice farmers in Manggungsari Village, Rajapolah District, Tasikmalaya Regency using the Survey Method. The analysis uses descriptive analysis and risk analysis (a Coefficient of Variation/ CV). The results showed that the types of risks faced by farmers in rice farming were disruption of crop pest organisms (pests, diseases and weeds), fluctuations in the price of grain/rice, slow construction of facilities (irrigation, roads, warehouses), damage to equipment production due to continuous use, and the difficulty in finding farm capital loans. Based on the analysis of risk shows that the risk of production, costs and income are categorized low. Furthermore, the method chosen by farmers in
\end{abstract}


dealing with risks before conducting rice farming or experiencing risks, farmers first make a joint plan with farmer groups and agricultural extension workers, during the production period when entering the dry season, more farmers to improve existing waterways for fear of drought land and after run the risk, farmers continue to do their farming while looking for other jobs to earn additional income.

Keywords: Risk, Farming, Rice, Riverbanks

\section{PENDAHULUAN}

Sektor pertanian sangat penting perannya dalam perekonomian nasional, sektor ini mampu memperoleh keuntungan yang manghasilkan devisa bagi negara. Sektor pertanian juga merupakan salah satu sektor yang dipersiapkan untuk menghasilkan produk yang memiliki kualitas dan nilai ekonomis, selain itu beberapa komoditas pertanian juga sudah menjadi bahan pangan pokok (makanan pokok) seharihari masyarakat di Indonesia seperti padi, ketela pohon, singkong dan jagung.

Hasil Sensus Pertanian 2013 (ST, 2013) menunjukkan bahwa jumlah rumah tangga usaha tanaman pangan (padi dan palawija) mencapai 17,73 juta rumah tangga atau 67,83 persen dari total jumlah rumah tangga usahatani, yang mencapai 26,14 juta rumah tangga pada tahun 2013 (BPS, 2015). Demikian pula data PDB Tahun 2015 memperlihatkan rata-rata kontribusi tanaman pangan menunjukkan share terbesar kedua setelah tanaman perkebunan yaitu sebesar 3,41\% dari total share pertanian sebesar $10,28 \%$ (Pusdatin, 2016).

Padi merupakan komoditas pertanian yang sangat banyak diproduksi oleh masyarakat tani Indonesia, mulai dari pulau Sumatra, Jawa, Kalimantan hingga Papua. Padi merupakan makanan pokok bagi masyarakat di Indonesia. Daerah di Indonesia yang banyak memproduksi padi adalah pulau Jawa, salah satu daerahnya berada di Kabupaten Tasikmalaya yaitu daerah penghasil padi bagian priangan timur Jawa Barat dengan rata-rata produksi kurun waktu 20082014 sebesar 809.771 ton dan produktivitas 6,346 ton/ha (BPS, 2015).

Sebaran pertanaman padi di Kabupaten Tasikmalaya merata hampir di setiap kecamatan, salah satunya adalah di Kecamatan Rajapolah. Pada tahun 2016 luas panen rata-rata mencapai 43 ha dengan produksi rata-rata mencapai 273 ton dan produktivitas rata-ratanya 6,35 ton/ha. Salahsatu desa di Kecamatan Rajapolah yang turut serta meberikan sumbangsih produksi padi adalah Desa Manggungsari, dengan lokasi pesawahan 
umumnya berada pada wilayah bantaran sungai citanduy. Peraturan Pemerintah Republik Indonesia No. 38 Tahun 2011 tentang sungai menyebutkan bahwa bantaran sungai adalah ruang antara tepi palung sungai dan kaki tanggul sebelah dalam yang terletak di kiri dan/atau kanan palung sungai. Hening (2005), menyatakan bahwa pemeliharaan bantaran sungai merupakan bagian dari daerah sungai yang bermanfaat untuk menampung dan mengalirkan air sebagai bagian dari aliran banjir. Dengan demikian, segala macam penghalang seperti tanaman-tanaman keras perlu ditebang dan tidak boleh ditanam kembali di sekitar bantaran.

Meskipun lokasi tanaman padi berada pada wilayah bantaran sungai yang menurut logika tidak akan kekurangan air, akan tetapi pada kenyataannya berdasarkan hasil observasi lapangan dan melalui wawancara dengan para petani, umumnya ketika memasuki musim penghujan sering terjadi kebanjiran yang menyebabkan kegagalan dan kerusakan tanaman padi serta mengakibatkan gagal panen. Kemudian ketika memasuki musim kemarau, petani kekurangan air untuk tanaman padi mereka. Pada musim kemarau para petani harus mengeluarkan biaya besar untuk usahatani padi yang dijalankan agar areal tanaman padi tetap digenangi air dengan cara membuat kincir tradisional sederhana yang terbuat dari bahan bambu dan kayu. Apabila hal tersebut tidak dilakukan maka areal sawah tetap menjadi kekeringan, sehingga apabila petani tetap berusahatani padi maka petani akan mengalami berbagai risiko dari kegiatan usahatani yang dijalankan pada wilayah bantaran sungai tersebut yang disebabkan oleh faktor alam.

Usahatani pada dasarnya merupakan proses pengorganisasian alam, lahan, tenaga kerja dan modal untuk menghasilkan output pertanian. Usahatani adalah ilmu yang mempelajari tentang cara petani mengelola input atau faktor-faktor produksi (tanah, tenaga kerja, teknologi, pupuk, benih, dan pestisida) dengan efektif, efisien, dan kontinyu untuk menghasilkan produksi yang tinggi sehingga pendapatan usahataninya meningkat (Rahim dan Hastuti, 2007).

Soekartawi (2002) berpendapat bahwa ilmu usahatani merupakan ilmu yang mempelajari bagaimana seseorang mengalokasikan faktor produksi yang ada secara efektif (dengan sebaik-baiknya) dan efisien (menghasilkan output yang melebihi input) untuk tujuan memperoleh 
keuntungan yang tinggi pada waktu tertentu. Adapun faktor produksi dalam usahatani ialah faktor alam yakni iklim dan tanah/lahan, tenaga kerja, modal, serta pengelolaan.

Usahatani adalah ilmu yang mempelajari bagaimana menggunakan sumberdaya secara efisien dan efektif pada suatu usaha pertanian agar diperoleh hasil maksimal. Sumber daya itu adalah lahan, tenaga kerja, modal dan manajemen (Shinta, 2011).

Suratiyah (2015) menyatakan bahwa ilmu usahatani adalah ilmu yang mempelajari bagaimana seorang mengusahakan dan mengkoordinir faktorfaktor produksi berupa lahan dan alam sekitarnya sebagai modal sehingga memberikan manfaat sebaik-baiknya. Sebagai ilmu pengetahuan, ilmu usahatani merupakan ilmu yang mempelajari cara-cara petani menentukan dan mengkoordinasikan penggunaan faktor-faktor produksi seefektif dan seefisien mungkin sehingga usaha tersebut memberikan pendapatan semaksimal mungkin. Lebih lanjut Suratiyah (2015) mendefinisikan usahatani sebagai segala kegiatan petani dalam mengusahakan dan mengkoordinasikan faktor-faktor produksi berupa lahan dan alam sekitarnya sebagai modal sehingga dapat memberikan manfaat/pendapatan sebaikbaiknya atau semaksimal mungkin.

Padi adalah tumbuhan yang mudah ditemukan, terutama di daerah pedesaan. Hamparan persawahan di pedesaan dipenuhi dengan tanaman padi. Tanaman tersebut digunakan sebagai sumber makanan pokok bagi masyarakat di Indonesia. Padi merupakan tanaman yang termasuk genus Oryza L. Padi (bahasa latin: Oryza sativa L.) merupakan salah satu tanaman budidaya terpenting dalam peradaban. Meskipun terutama mengacu pada jenis tanaman budidaya, padi juga digunakan untuk mengacu pada beberapa jenis dari marga (genus) yang sama, yang biasa disebut sebagai padi liar.

Tanaman padi dapat hidup baik di daerah yang berhawa panas maupun daerah yang banyak mengandung uap air. Curah hujan yang baik rata-rata $200 \mathrm{~mm}$ per bulan atau lebih, dengan distribusi selama 4 bulan, curah hujan yang dikehendaki per tahun sekitar 1.500$2.000 \mathrm{~mm}$. Suhu yang baik untuk pertumbuhan tanaman padi $23^{\circ} \mathrm{C}$. Tinggi tempat yang cocok untuk tanaman padi berkisar antara 0-1.500 m dpl. Tanah yang baik untuk pertumbuhan tanaman padi adalah tanah sawah yang kandungan fraksi pasir, debu dan lempung dalam 
perbandingan tertentu dengan diperlukan air dalam jumlah yang cukup. Padi dapat tumbuh dengan baik pada tanah yang ketebalan lapisan atasnya antara 18-22 cm dengan $\mathrm{pH}$ antara 4-7.

Manurut KBBI, bantaran sungai adalah jalur tanah pada kanan dan kiri sungai (antara sungai dan tanggul). Lebih lanjut dalam Peraturan Pemerintah RI No. 38 Tahun 2011 tentang sungai disebutkan bahwa bantaran sungai adalah ruang antara tepi palung sungai dan kaki tanggul sebelah dalam yang terletak dikiri dan/atau kanan palung sungai.

Risiko merupakan suatu hal yang harus dihadapi siapa saja, termasuk dalam hal ini adalah para petani padi. Tindakan untuk menghindari risiko merupakan hal yang cukup sulit dilakukan, sehingga yang paling mudah ialah bagaimana mengelola risiko tersebut dengan baik. Risiko yang dikelola dengan baik akan meminimalisir kerugian yang diderita, maka dari itu, risiko dalam kegiatan usaha merupakan hal yang penting untuk diperhatikan. Robison dan Barry (1987) menyatakan bahwa seorang pengambil keputusan harus memperhatikan tiga hal penting yang berkaitan dengan risiko, yakni seberapa besar kemampuan risiko yang akan mempengaruhi seluruh kombinasi keputusan yang dibuat dalam bisnis, sumber informasi apa yang tersedia untuk memprediksi risiko bisnis yang akan dihadapi, dan alternatif apa saja yang tersedia untuk meminimalisir risiko bisnis yang dihadapi.

Risiko yang paling umum ditemui bisa dibagi ke dalam tiga kategori: keuangan, operasional, dan strategis. Selain itu, risiko bisa bersifat internal atau eksternal kelembagaan. Risiko internal sebagian besar berada dalam kendali petani karena terkait dengan sistem operasional dan keputusan manajemen. Risiko eksternal sebagian besar di luar kendali petani dikarenakan terkait dengan alam seperti bencana alam serta cuaca yang tidak menentu (Goldberg dan Palladini, 2011).

Menurut Soedjana (2007), istilah risiko lebih banyak digunakan dalam konteks pengambilan keputusan, karena risiko diartikan sebagai peluang akan terjadinya suatu kejadian buruk akibat suatu tindakan. Makin tinggi tingkat ketidakpastian suatu kejadian, makin tinggi pula risiko yang disebabkan oleh pengambilan keputusan itu. Dengan demikian, identifikasi sumber risiko sangat penting dalam proses pengambilan keputusan. 
Darmawi (2016) menyatakan bahwa informasi mengenai risiko yang diperlukan berkenaan dengan dua dimensi risiko yang perlu diukur ialah frekuensi atau jumlah kerugian yang akan terjadi, dan keparahan dari kerugian itu. Paling sedikit untuk masing-masing dimensi itu yang ingin diketahui adalah;

a. Rata-rata nilainya dalam periode anggaran.

b. Variasi nilai dari yang diharapkan dengan yang aktual.

c. Dampak keseluruhan dari kerugiankerugian itu.

Kehidupan petani di pedesaan cukup dekat dengan batas subsisten dan selalu mengalami ketidakpastian cuaca, sehingga petani tidak mempunyai kesempatan untuk menerapkan perhitungan keuntungan maksimum dalam berusahatani. Petani akan berusaha menghindari kegagalan dan bukan memperoleh keuntungan yang besar dengan mengambil risiko (Sriyadi, 2010). Berbagai permasalahan yang dihadapi petani tersebut menjadi kendala bagi mereka untuk meningkatkan produksi, pendapatan dan mewujudkan ketahanan pangan rumahtangganya. Permasalahanpermasalahan tersebut merupakan risiko yang harus dihadapi oleh petani dalam melakukan aktivitas usahataninya.
Terdapat beberapa macam risiko yang dihadapi petani padi yaitu risiko produksi, risiko harga, risiko institusi, risiko sumber daya manusia (SDM) dan risiko keuangan, sebagian risiko dapat dihitung karena dalam bentuk nominal/angka yaitu risiko produksi, risiko harga dan risiko keuangan. Akibat dari terjadinya sebuah risiko dalam usahatani padi akan memunculkan bagaimana cara petani dalam menghadapi risiko-risiko tersebut.

$$
\text { Suharyanto, dkk }
$$

menyatakan bahwa risiko produksi usahatani padi sawah yang diusahakan pada musim kemarau memiliki risiko produksi yang lebih rendah dibandingkan pada musim hujan. Risiko produksi padi sawah juga lebih tinggi pada lahan bukan milik dibandingkan lahan dengan status milik sendiri.

Saputra (2017) mengemukakan bahwa risiko produksi, biaya dan pendapatan pada usahatani padi di daerah perbukitan risikonya rendah. Cara yang dipilih oleh petani dalam mengendalikan risiko: a) sebelum melakukan usahatani padi petani atau mengalami risiko, petani terlebih dahulu membuat perencanaan bersama kelompok tani dan penyuluh pertanian, b) pada saat masa produksi apabila terserang hama dan penyakit 
petani lebih banyak memilih untuk membasmi hama dengan menggunakan pestisida yang lebih cepat dan terbukti, walaupun petani sudah mengetahui dampaknya, dan c) setelah mengalami risiko, petani tetap melakukan/ menyelesaikan usahataninya walaupun produksi padi tidak sesuai dengan yang diharapkan.

Rama, dkk (2016) menyatakan bahwa terdapat perbedaan risiko antara usahatani lahan basah dan lahan kering dimana risiko produksi padi lahan basah lebih besar jika dibandingkan dengan risiko lahan kering.

Debertin (2012), menyatakan bahwa setiap petani memiliki perbedaan kriteria perilaku dalam menghadapi risiko yang dihadapi terdiri atas risk averse, risk neutral dan risk taker. Petani yang risk averse merupakan perilaku petani yang tidak siap untuk menghadapi kerugian, petani akan mengharapkan pendapatan yang lebih tinggi jika menghadapi risiko yang tinggi. Perilaku risk taker pada petani yang berani mengambil kesempatan walaupun hasil yang diperoleh rendah, pendapatan rendah yang dihadapi petani tidak mempengaruhi keinginan petani untuk menjalankan kegiatan produksinya. Petani risk neutral menunjukkan perilaku yang tidak peka terhadap besar atau kecilnya risiko yang dihadapi.

Penelitian ini mencoba mengidentifikasi macam-macam risiko usahatani padi yang dilakukan para petani, kemudian menganalisis besaran risiko yang berkaitan dengan produksi, biaya dan pendapatan dari kegiatan usahatani padi, serta mengetahui caracara yang dilakukan para petani dalam menghadapi risiko usahatani yang dilakukan pada wilayah bantaran sungai citanduy di Kampung/Desa Manggungsari Kecamatan Rajapolah Kabupaten Tasikmalaya.

\section{METODE PENELITIAN}

Metode penelitian dilakukan dengan pendekatan observasi, survey dan kepustakaan. Teknik penentuan lokasi penelitian dipilih secara sengaja (purposive). Sugiyono menyatakan bahwa purposive sampling merupakan teknik penentuan sampel dengan pertimbangan tertentu. Penelitian dilakukan dari bulan April-Novemver 2019.

Responden dalam penelitian ini adalah petani padi yang melakukan usahatani padi pada wilayah bantaran sungai citanduy dengan jumlah populasi sebanyak 312 orang, dengan pengambilan 
sampel sebesar sepuluh persen (31 orang). teknik pengambilan dilakukan menggunakan simple random sampling. Sugiyono (2009) menyatakan bahwa simple random sampling merupakan prosedur pengambilan sampel dari populasi yang dilakukan secara acak tanpa memperhatikan strata yang ada dalam populasi.

Beberapa pengertian dalam penelitian ini dioperasionalisasikan sebagai berikut:

1. Risiko merupakan peluang terjadinya kemungkinan kerugian yang probabilitasnya dapat diketahui terlebih dahulu dengan nilai koefisien variasi $(\mathrm{CV})$, simpangan baku $(\sigma)$ dan nilai rata-rata $(\mathrm{Xr})$ dari pendapatan yang diterima petani selama musim tanam terakhir.

2. Koefisien variasi $(\mathrm{KV} / \mathrm{CV})$ adalah perbandingan risiko yang harus ditanggung petani dengan jumlah keuntungan yang akan diperoleh dengan hasil dan sejumlah modal yang ditanamkan dalam proses produksi padi. Koefisien variasi (CV) diperoleh dengan membagi simpangan baku atau standar deviasi $(\sigma)$ dengan nilai yang diharapkan.

3. Standar deviasi atau simpangan baku ( $\sigma)$ adalah ukuran satuan risiko terkecil yang menggambarkan penyimpangan yang terjadi dari usahatani padi dan akar dari ragam atau varian $\left(\sigma^{2}\right)$.

4. Nilai rata-rata $(\mathrm{Xr})$ adalah nilai yang diperoleh dari seluruh produksi, biaya dan pendapatan petani padi.

5. Usahatani padi merupakan kegiatan usahatani padi pada wilayah bantaran sungai citanduy, umumnya dilakukan 3 kali dalam satu tahun. Perbedaan yang mencolok terlihat pada kegiatan usahatani yang dilakukan ketika musim kemarau dimana petani harus mengambil air dengan menggunakan kincir tradisonal yang terbuat dari bambu.

6. Petani padi adalah semua petani yang berusahatani padi dan memperoleh pendapatan dari usahataninya.

7. Wilayah bantaran sungai merupakan jalur tanah pada kanan dan kiri sungai (antara sungai dan tanggul) tempat petani melakukan kegiatan usahatani padi.

Analisis untuk mengidentifikasi macam-macam risiko menggunakan analisis deskriptif, yang meliputi: a) Risiko hasil produksi, b) Risiko harga atau pasar, c) Risiko institusi, d) Risiko manusia, dan e) Risiko keuangan. Analisis ini menggambarkan macam- 
macam risiko yang dihadapi petani padi pada wilayah bantaran sungai citanduy di lokasi penelitian. Analisis kuantitatif digunakan untuk mengukur risiko produksi, biaya dan pendapatan dengan menggunakan Koefisien Variasi (CV) yang merupakan ukuran risiko relatif yang diperoleh dengan membagi standar deviasi dengan nilai yang diharapkan dengan rumus (Pappas dan Hirschey, 1995):

$$
C V=\frac{\sigma}{X r}
$$

Keterangan:

$\mathrm{CV} \quad=$ Koefisien variasi

$\sigma \quad=$ Standar deviasi (simpangan baku)

$\mathrm{Xr} \quad=$ Nilai rata-rata

Nilai koefisien variasi yang lebih kecil menunjukkan variabilitas nilai ratarata pada distribusi tersebut rendah. Hal ini menggambarkan risiko yang dihadapi untuk memperoleh produksi tersebut rendah. Untuk menentukan hipotesis nol (Ho) dan hipotesis alternatif ( $\mathrm{Ha})$, dlakukan dengan:

Ho: Diduga risiko usahatani yang dihadapi petani padi pada wilayah bantaran sungai citanduy tinggi.
Ha: Diduga risiko usahatani yang dihadapi petani padi pada wilayah bantaran sungai citanduy rendah.

Dasar pengambilan keputusan:

Ho: $\mathrm{CV} \geq 0,5$ Ho diterima dan $\mathrm{Ha}$ ditolak jika risiko usahatani pada wilayah bantaran sungai citanduy tinggi, dan

$\mathrm{Ha}: \mathrm{CV}<0,5$, Ha diterima dan Ho ditolak jika risiko usahatani pada wilayah bantaran sungai citanduy rendah.

Selanjutnya, untuk mengetahui cara petani dalam menghadapi risiko usahatani menggunakan analisis deskriptif. Analisis ini menggambarkan tentang cara yang dilakukan oleh petani padi pada wilayah bantaran sungai citanduy dalam menghadapi risiko usahataninya, yang meliputi sebelum terjadinya risiko, dalam masa produksi, dan setelah mengalami risiko.

\section{HASIL DAN PEMBAHASAN}

\section{Jenis Risiko yang Dihadapi Petani Berdasarkan Sumbernya}

1. Risiko yang bersumber dari produksi

Sumber risiko dari produksi merupakan jenis risiko yang ditimbulkan oleh adanya fluktuasi produksi. Hasil penelitian menunjukkan bahwa risiko yang dihadapi oleh petani padi pada 
wilayah bantaran sungai citanduy diakibatkan oleh adanya perubahan iklim (tidak adanya hujan atau terjadinya kemarau yang panjang), bencana alam (banjir, longsor), gangguan organisme pengganggu tanaman/OPT (hama, penyakit dan gulma) dan sulitnya mendapat bibit/benih yang berkualitas. Mayoritas petani menganggap bahwa perubahan iklim, bencana alam, gangguan OPT dan sulitnya mendapatkan bibit/benih yang berkualitas sangat berpengaruh dan mengganggu dalam usahatani padi pada wilayah bantaran sungai citanduy, terlebih pada musim panen terakhir tanaman padi milik petani tidak dapat dipanen secara maksimal, hal tersebut disebabkan oleh terjadinya kekeringan akibat musim kemarau yang panjang. Untuk lebih jelasnya dapat dilihat pada Tabel 1.

Tabel 1. Risiko yang Bersumber dari Produksi

\begin{tabular}{clc}
\hline No & \multicolumn{1}{c}{ Jenis Risiko } & Jumlah (orang) \\
\hline 1. & Perubahan iklim/cuaca yang ekstrem dan tidak menentu & 28 \\
2. & Bencana alam (banjir, longsor dan kekeringan) & 26 \\
3. & Gangguan organisme pengganggu tanaman (hama, penyakit dan gulma) & 31 \\
4. & Sulitnya mendapatkan bibit/benih yang berkualitas & 22 \\
\hline
\end{tabular}

Sumber: Data Primer Diolah (2019)

2. Risiko yang bersumber dari pasar/harga

Risiko pasar/harga merupakan risiko yang terkait dengan permintaan dan penawaran produk-produk pertanian yang dihadapi petani padi pada wilayah bantaran sungai citanduy. Petani menyatakan bahwa risiko yang dihadapi adalah ketika harga jual gabah yang fluktuatif. Petani menerangkan apabila harga jual gabah naik turun menyebabkan petani ragu untuk menjual hasil panennya, jika harga turun petani akan merugi namun apabila naik petani mendapat keuntungan, hal yang paling sulit di prediksi yaitu kapan terjadinya naik dan turun harga tersebut. Harga input produksi yang mahal juga menjadi masalah bagi petani, hal tersebut terbukti dengan banyaknya petani yang menyatakan bahwa petani merasa kesulitan untuk mencari input produksi untuk usahatani padi dengan harga yang cukup murah dan terjangkau sehingga tidak mnyebabkan biaya produksi yang tinggi. Kemudian risiko yang berikutnya juga timbul dari biaya tenaga kerja di sektor pertanian yang semakin naik/tinggi ditambah sudak semakin jarangnya tenaga muda yang tertarik bekerja di sektor pertanian menyebabkan sulitnya mencari tenaga kerja yang murah. Lebih jelasnya dapat dilihat pada Tabel 2. 
Tabel 2. Risiko yang Bersumber dari Pasar/Harga

\begin{tabular}{clc}
\hline No & \multicolumn{1}{c}{ Jenis Risiko } & Jumlah (orang) \\
\hline 1. & Harga jual gabah/beras fluktuatif/naik-turun & 31 \\
2. & Harga input (pupuk, bibit/benih, dan pestisida) yang mahal & 27 \\
3. & Permintaan pasar terhadap beras berkurang & 0 \\
4. & Biaya tenaga kerja yang semakin naik/tinggi dan jarang & 17 \\
\hline
\end{tabular}
Sumber: Data Primer Diolah (2019)

3. Risiko yang bersumber dari institusi

Risiko institusi dalam hal ini merupakan risiko yang disebabkan dan berasal dari lembaga/pemerintahan yang dapat mempengaruhi produksi dalam kegiatan usahatani yang dilakukan oleh petani. Berdasarkan hasil penelitian yang telah dilakukan, petani menganggap bahwa penyuluh pertanian yang ada di daerah penelitian kurang aktif dalam memberikan pemahaman dan menyampaikan informasi terkait usahatani padi terutama untuk kegiatan usahatani padi yang berada pada wilayah bantaran sungai citanduy. Petani juga beranggapan bahwa kebijakan pemerintah banyak yang kurang memihak kepada petani kecil yaitu terkait dengan penetapan harga dan pengawasan dalam pemasaran yang masih lemah sehingga petani dirugikan dengan adanya tengkulak. Selanjutnya, petani beranggapan bahwa lambatnya pembangunan/fasilitasi dalam bidang pertanian yang dilakukan oleh pemerintah seperti irigasi, jalan, gudang dan lain-lain merupakan risiko bagi petani, dimana irigasi tentunya akan membuat kegiatan usahatani padi semakin lancar karena ketersediaan air selalu ada sepanjang musim. Kemudian yang tidak kalah pentingnya juga terkait anggapan petani bahwa masih sedikitnya sumbangsih dan peran serta perguruan tinggi sekitar dalam menyampaikan inovasi dan teknologi baru di bidang pertanian. Petani menganggap bahwa semua hal tersebut sangat penting sebagai penunjang dalam menjalankan usahataninya, semakin aktif peran penyuluh pertanian di wilayah sekitar, semakin baik/bagus kebijakannya terhadap petani dan pembangunan yang merata, cepat dan tepat serta semakin banyaknya sumbangan inovasi teknologi di bidang pertanian dari perguruan tinggi sekitar akan dapat meningkatkan pendapatan, taraf hidup dan kesejahteraan bagi petani padi pada wilayah bantaran sungai citanduy. Lebih jelasnya dapat dilihan pada Tabel 3. 
Tabel 3. Risiko yang Bersumber dari Institusi

\begin{tabular}{clc}
\hline No & \multicolumn{1}{c}{ Jenis Risiko } & Jumlah (orang) \\
\hline 1. & $\begin{array}{l}\text { Tidak adanya penyuluh pertanian yang memberikan penyuluhan di Ds/Kp. } \\
\text { Manggungsari }\end{array}$ & 20 \\
\hline 2. & Kebijakan pemerintah yang kurang memihak kepada petani kecil/rakyat. & 23 \\
\hline 3. & $\begin{array}{l}\text { Lambatnya pembangunan/fasilitasi pertanian yang dilakukan oleh pemerintah } \\
\text { seperti pembangunan irigasi, jalan, gudang, dll. }\end{array}$ & 26 \\
\hline 4. & Kurangnya sumbangan inovasi teknologi dari perguruan tinggi & 18 \\
\hline
\end{tabular}
Sumber: Data Primer Diolah (2019)

4. Risiko yang bersumber dari manusia

Risiko yang bersumber dari manusia merupakan risiko yang disebabkan oleh perilaku manusia dalam kegiatan usahatani padi sehingga mempengaruhi terhadap produksi padi. Hasil penelitian menunjukkan bahwa petani menganggap semua risiko yang bersumber atau disebabkan oleh manusia berpengaruh terhadap produksi usahatani padi pada wilayah bantaran sungai citanduy. Risikorisiko tersebut diantaranya kerusakan alatalat produksi seperti cangkul, traktor, sabit, mesin perontok padi dan lain-lain karena penggunaan yang terus menerus. Kemudian, terganggunya kesehatan petani dalam kegiatan usahatani padi yang diakibatkan oleh kebanyakan usia petani yang sudah tidak muda lagi menjadi risiko yang bisa mengakibatkan produksi usahataninya menjadi lambat dan bahkan terbengkalai. Kemudian, hilangnya alatalat produksi pertanian yang disebabkan karena ada yang mencuri atau meminjam tanpa pemberitahuan dan akibat terjadinya kebakaran, baik itu lupa pada saat di sawah maupun ketika disimpan di rumah, mengakibatkan risiko dalam usahatani padi karena petani harus kembali mengeluarkan biaya untuk pengadaan alat-alat tersebut. Selanjutnya yang terakhir yang menjadi risiko usahatani padi ialah berkurangnya tenaga kerja dalam kegiatan produksi seperti menanam dan memanen karena rendahnya minat kaum muda utnuk terjun di sektor pertanian. Lebih jelasnya dapat dilihat pada Tabel 4.

Tabel 4. Risiko yang Bersumber dari Manusia

\begin{tabular}{cllc}
\hline No & \multicolumn{1}{c}{ Jenis Risiko } & Jumlah (orang) \\
\hline 1. & $\begin{array}{l}\text { Kerusakan alat-alat produksi (cangkul, traktor, sabit, mesin perontok, dll) } \\
\text { karena penggunaan yang terus menerus. }\end{array}$ & 31 \\
\hline 2. & $\begin{array}{l}\text { Kesehatan petani yang terganggu sehingga menyebabkan produksi } \\
\text { usahataninya menjadi lambat/terbengkalai. }\end{array}$ & 27 \\
\hline 3. & Hilangnya alat produksi pertanian karena dicuri atau terkena kebakaran. & 9 \\
\hline 4. & $\begin{array}{l}\text { Berkurangnya tenaga kerja dalam kegiatan produksi seperti menanam dan } \\
\text { memanen, dll. }\end{array}$ & 18 \\
\hline
\end{tabular}

Sumber: Data Primer Diolah (2019) 
5. Risiko yang bersumber dari keuangan

Risiko yang bersumber dari keuangan merupakan dampak bagi seorang petani akibat dari cara petani mengelola keuangannya dalam kegiatan usahatani. Hasil penelitian menunjukkan bahwa risiko keuangan timbul diakibatkan dari kepemilikan modal yang sedikit untuk kegiatan usahatani padi, petani biasanya merasa bahwa kegiatan usahatani padi merupakan rutinitas sehingga sering tidak terencanakan dengan baik. Risiko selanjutnya yaitu diakibatkan tidak adanya lembaga keuangan yang memberikan pinjaman modal untuk usahatani (padi), kebanyakan lembaga keuangan masih enggan untuk masuk ke sektor pertanian karena dianggap kurang populer dan memiliki risiko dan ketidakpastian yang tinggi ditambah lagi pinjaman di bank yang sulit karena suku bunga yang tidak sesuai untuk kegiatan usahatani padi, dimana hal tersebut dikarenakan sebagian besar petani merasa takut untuk meminjam ke bank yang menggunakan jaminan. Kemudian risiko keuangan timbul diakibatkan dari pengeluaran kebutuhan rumah tangga yang tidak sebanding dengan hasil dari usahatani, karena kebanyakan kegiatan usahatani yang dilakukan petani dilokasi penelitian merupakan subsisten. Labih jelasnya dapat dilihat pada Tabel 5.

Tabel 5. Risiko yang Bersumber dari Keuangan

\begin{tabular}{clc}
\hline No & \multicolumn{1}{c}{ Jenis Risiko } & Jumlah (orang) \\
\hline 1. & Modal yang dimiliki untuk usahatani padi sedikit & 29 \\
\hline 2. & $\begin{array}{l}\text { Tidak adanya koperasi/lembaga keuangan yang memberikan pinjaman modal } \\
\text { untuk usahatani/petani. }\end{array}$ & 31 \\
\hline 3. & $\begin{array}{l}\text { Pengeluaran kebutuhan rumah tangga yang tinggi, sehingga tidak sebanding } \\
\text { dengan hasil dari usahatani padi. }\end{array}$ & 30 \\
\hline 4. & Pinjaman di Bank yang sulit dikarenakan (suku bunga pinjaman yang tinggi) & 17 \\
\hline
\end{tabular}

Sumber: Data Primer Diolah (2019)

\section{Risiko Biaya, Produksi dan Pendapatan} Ushatani Padi

Terdapat beberapa karakteristik rumah tangga petani berkaitan penting terhadap perilaku petani dalam menghadapi risiko dan strategi manajemen risiko yang digunakan dalam menghadapinya, diantaranya: 1) Struktur umur; 2) Jumlah tanggungan keluarga, 3)
Jenis kelamin dan tingkat pendidikan, 4) Pengalaman berusahatani; dan 5) Struktur pendapatan.

Struktur umur petani, umur akan mempengaruhi perilakunya dalam menghadapi risiko. Petani yang masih berumur produktif akan lebih reaktif dalam menghadapi suatu risiko dalam kegiatan usahataninya, petani akan 
berusaha lebih keras untuk mengurangi dampak negatif yang diakibatkan dari adanya risiko dalam usahatani.

Jumlah tanggungan keluarga, jumlah anggota dikeluarga merupakan beban yang harus ditanggung oleh petani didalam rumah tangganya, secara teoritis semakin banyak beban tanggungan maka semakin besar pula usaha yang akan dilakukan untuk mengurangi risiko yang dihadapi dimana apabila terjadi kegagalan panen dalam usahatani padi merupakan suatu ancaman bagi pemenuhan kebutuhan pangan seluruh anggota rumah tangganya.

Jenis kelamin petani dan tingkat pendidikan petani dapat mempengaruhi perilaku petani dalam menghadapi risiko. Petani dengan jenis kelamin laki-laki akan lebih kuat dan aktif dibandingkan dengan petani perempuan dalam mengatasi suatu risiko agar dampaknya menjadi lebih kecil. Kemudian tingkat pendidikan petani yang semakin tinggi akan lebih bijak dalam mengambil keputusan untuk mengatasi suatu risiko yang dihadapi.

Struktur pendapatan dalam mengatasi risiko yang dihadapi oleh petani akan sangat mempengaruhi. Petani dengan pendapatan yang lebih besar akan melakukan berbagai strategi dalam menghadapi risiko untuk dapat mereduksi risiko usahatani yang dihadapinya dan sebaliknya petani dengan pendapatan yang terbatas akan terhambat untuk dapat mengatasi/menekan risiko usahataninya. Petani padi yang berada pada wilayah bantaran sungai citanduy di Kp//Ds. Manggungsari selain melakukan usahatani padi, juga mempunyai usaha sampingan lain diantaranya beternak kambing/domba, berdagang, usaha kerajinan tangan, buruh bangunan dan buruh tani. Kegiatan sampingan tersebut dilakukan sebagai salah satu upaya alternatif petani dalam mengantisipasi apabila terjadinya risiko usahatani padi yang dilakukannya.

Hasil perhitungan mengenai besarnya risiko biaya, produksi dan pendapatan usahatani padi pada wilayah bantaran sungai citanduy di Kp/Ds. Manggungsari ditunjukkan pada Tabel 6.

Tabel 6. Besaran Risiko Biaya, Produksi dan Pendapatan

\begin{tabular}{clcl}
\hline No & Jenis Risiko & $\begin{array}{c}\text { Nilai } \\
\text { KV }\end{array}$ & Kategori \\
\hline 1. & Biaya & 0,37 & Rendah \\
\hline 2. & Produksi & 0,46 & Rendah \\
\hline 3. & Pendapatan & 0,41 & Rendah \\
\hline \multicolumn{2}{c}{ Sumber: Data Primer Diolah (2019) } \\
\multicolumn{2}{c}{ Tabel 6 menunjukkan } & bahwa
\end{tabular}
perolehan nilai $\mathrm{KV}$ untuk masing-masing jenis risiko, baik untuk biaya sebesar 0,37 , untuk produksi sebesar 0,46 dan untuk pendapatan sebesar 0,41. Maka dapat disimpulkan bahwa risiko biaya, produksi dan pendapatan termasuk kategori rendah 
karena nilai $\mathrm{KV}$ dari masing-masing risiko kurang dari 0,5 atau dengan kata lain $\mathrm{Ha}$ diterima dan $\mathrm{H}_{0}$ ditolak.

Biaya yang dikeluarkan petani untuk melakukan usahatani padi pada pada wilayah bantaran sungai citanduy di $\mathrm{Kp} / \mathrm{Ds}$. Manggungsari rata-rata sebesar Rp 1.258.250 dengan KV sebesar 0,37 artinya risiko biaya yang dikeluarkan petani padi adalah rendah, hal ini dikarenakan biayabiaya untuk melakukan usahatani padi pada wilayah bantaran sungai citanduy di Kp/Ds. Manggungsari masih tergolong murah seperti harga pupuk, pestisida, dan upah tenaga kerja meskipun petani beranggapan bahwa tersebut sudah cukup mahal tetapi masih berada pada kisaran normal. Hal Tersebut berbeda dengan penelitian Misqi dan Karyani (2020), pada komoditas cabai dengan nilai $\mathrm{CV}$ mencapai 1,25 yang menyatakan bahwa peluang risiko biaya dalam melakukan usahatani cabai merah besar tinggi, penyebab tingginya risiko tersebut karena banyaknya biaya yang dikeluarkan oleh petani dalam hal penggunaan input.

Rata-rata produksi padi yang didapat petani sebesar $985 \mathrm{Kg}$ dan ratarata penerimaan dalam satu musim tanam sebesar Rp 5.516.000,- dengan KV sebesar 0,46 artinya risiko produksi padi pada wilayah bantaran sungai citanduy di
Kp/Ds. Manggungsari dikategorikan rendah, karena dalam melakukan usahatani padi petani tidak banyak mengalami kendala selain dari keurangan air apabila memasuki musim kemarau dan mengalami kebanjiran apabila musim penghujan tiba, serta gangguan hama penyakit yang menyerang tanaman padi. Hal tersebut sejalan dengan penelitian Suharyanto, dkk. (2015) yang menunjukkan risiko usahatani padi sawah di Provinsi Bali berdasarkan musim tanam tergolong kecil dengan CV 0,136 (musim hujan) dan CV 0,078 (musim hujan).

Rata-rata pendapatan petani dalam melakukan usahatani padi pada wilayah bantaran sungai citanduy di Kp/Ds. Manggungsari dalam satu musim tanam sebesar Rp 4.257.750,- meskipun rata-rata pendapatan dari usahatani padi tergolong kecil, tetapi petani memperoleh pendapatan sampingan dari selain usahatani padi (beternak kambing atau domba, berdagang, usaha kerajinan tangan, buruh bangunan dan buruh tani) dengan rata-rata sebesar $\mathrm{Rp} 985.500$ dengan nilai KV 0,41 yang artinya risiko pendapatan petani dikategorikan rendah hal tersebut karena jumlah produksi yang cukup tinggi dan ditunjang dengan harga jual padi GKG sekitar Rp 560.000/kw pada saat penelitian. Hasil tersebut sejalan 
dengan penelitian Saputra (2017) yang menunjukkan bahwa risiko ushatani padi di wilayah perbukitan tergolong rendah dengan CV mencapai 0,30 karena harga jual GKG yang cukup tinggi sehingga petani masih bisa menutupi biaya untuk kegiatan usahataninya.

\section{Strategi Petani dalam Menghadapi Risiko pada Usahatani Padi}

Dalam pengelolaan suatu risiko diperlukan adanya strategi tentang bagaimana menghadapi risiko tersebut, strategi dalam menghadapi risiko usahatani padi dimulai dari sebelum risiko itu terjadi, pada saat masa produksi dan setelah mengalami atau risiko tersebut terjadi.

Sebelum terjadinya risiko, petani banyak memilih untuk membuat perencanaan sebelum melakukan usahatani padi bersama kelompok tani dan penyuluh dengan jumlah petani sebanyak
18 orang $(58,06 \%)$. Petani yang memilih untuk membuat prediksi dengan patokan musim untuk menghindari kekeringan sebanyak 5 orang $(16,13 \%)$. Petani yang memilih untuk mengurangi biaya input (modal), seperti mengurangi penggunaan pupuk yang dibeli dan beralih ke pupuk organik yang tersedia sebanyak 2 orang $(6,45 \%)$, dan petani yang memilih untuk membuat persiapan yang matang, seperti mempersiapkan segala faktor penunjang produksi usahatani padi sebanyak 6 orang $(19,35 \%)$. Semua hal tersebut dilakukan petani dengan alasan untuk menghemat biaya apabila sewaktu-waktu terjadi risiko, biaya yang dialokasikan nantinya bisa dialihfungsikan kepada usaha lainnya sebagai alternatif (solusi) sehingga petani tetap bisa menghasilkan pendapatan untuk menghidupi keluarganya. Lebih jelasnya dapat dilihat pada Tabel 7.

Tabel 7. Strategi Petani Dalam Menghadapi Risiko Usahatani Sebelum Terjadinya Risiko.

\begin{tabular}{llcc}
\hline No & \multicolumn{1}{c}{ Jenis Kegiatan } & $\begin{array}{c}\text { Jumlah } \\
\text { (Orang) }\end{array}$ & $\begin{array}{c}\text { Persentase } \\
(\%)\end{array}$ \\
\hline 1. & $\begin{array}{l}\text { Membuat perencanaan sebelum melakukan usahatani padi bersama } \\
\text { kelompok tani dan penyuluh, agar petani siap jika terjadi masalah/risiko. }\end{array}$ & 18 & 58,06 \\
2. $\begin{array}{l}\text { Membuat prediksi dengan patokan musim, guna untuk menghindari } \\
\text { kekeringan. }\end{array}$ & 5 & 16,13 \\
3. $\begin{array}{l}\text { Mengurangi biaya input (modal), seperti mengurangi penggunaan pupuk } \\
\text { yang dibeli dan beralih ke pupuk organik yang tersedia. }\end{array}$ & 2 & 6,45 \\
$\begin{array}{l}\text { 4embuat persiapan yang matang, seperti mempersiapkan segala faktor } \\
\text { penunjang produksi usahatani padi (contoh: pengolahan lahan, irigasi dll). }\end{array}$ & 6 & 19,35 \\
\hline
\end{tabular}

Sumber: Data Primer Diolah (2019)

Pada saat masa produksi, petani melakukan berbagai cara/solusi untuk mengatasi risiko yang terjadi dimana salah satu yang paling sering dilakukan oleh 
kebanyakan petani padi pada wilayah bantaran sungai citanduy adalah melakukan perawatan irigasi atau saluran air dari sungai secara terus menerus terutama dengan membuat kincir sederhana dari bambu/kayu, hal tersebut dilakukan oleh petani agar lahan mereka tetap dapat teraliri oleh air sehingga produksi padi tetap terus berjalan dan terhindar dari kegagalan panen meskipun para petani harus mengeluarkan uang lebih untuk pembuatannya dimana untuk pembuatan satu buah kincir biaya yang harus dikeluarkan berkisa antara $\mathrm{Rp}$ 500.000 - Rp 750.000 dengan jumlah petani yang memilih sebanyak 11 orang (35,48\%). Sebanyak 8 orang $(25,81 \%)$ memilih untuk melakukan pengendalian hama dengan menggunakan pestisida (buatan dan nabati), hal tersebut dilakukan petani agar tanaman padi mereka terhindar dan aman dari gangguan hama dan penyakit sehingga hasil panen tidak banyak berkurang. Sebanyak 6 orang $(19,35 \%)$ petani memilih melakukan pengaturan penggunaan pupuk yang digunakan antara musim kering dan penghujan dimana hal tersebut dilakukan guna lebih mengurangi pengeluaran biaya produksi agar sebanding dengan kemungkinan hasil yang didapat sehingga tidak terlalu banyak merugi, dan sebanyak 6 orang (19,35\%) lebih memilih untuk melakukan metode penanaman yang benar dan sesuai anjuran (seperti jarak tanam padi, dll), hal tersebut dilakukan karena sebagian petani beranggapan bahwa dengan melakukan jarak tanam sesuai anjuran akan dapat meningkatkan hasil produksi dan pendapatan dari usahatani padi yang dilakukannya. Lebih jelasnya dapat dilihat pada Tabel 8 .

Tabel 8. Strategi Petani Dalam Menghadapi Risiko Usahatani pada Masa Produksi

\begin{tabular}{clcc}
\hline No & \multicolumn{1}{c}{ Jenis Kegiatan } & $\begin{array}{c}\text { Jumlah } \\
\text { (Orang) }\end{array}$ & $\begin{array}{c}\text { Persentase } \\
(\%)\end{array}$ \\
\hline 1. & $\begin{array}{l}\text { Melakukan metode penanaman yang benar dan sesuai anjuran (seperti } \\
\text { jarak tanam padi, dll) }\end{array}$ & 6 & 19,35 \\
2. & $\begin{array}{l}\text { Melakukan pengaturan Penggunaan Pupuk yang digunakan antara musim } \\
\text { kering dan penghujan. }\end{array}$ & 6 & 19,35 \\
3. & $\begin{array}{l}\text { Melakukan pengendalian hama dengan menggunakan pestisida (buatan, } \\
\text { nabati) }\end{array}$ & 8 & 25,81 \\
4. $\begin{array}{l}\text { Melakukan perawatan irigasi atau saluran air dari sungai secara terus } \\
\text { menerus agar terhindar dari kekeringan. }\end{array}$ & 11 & 35,48 \\
\hline
\end{tabular}

Sumber: Data Primer Diolah (2019)

Masa setelah mengalami risiko, merupakan masa dimana risiko pada usahatani padi telah terjadi dan petani mengalami kerugian akibat risiko tersebut. Petani padi pada wilayah bantaran sungai citanduy sebagian besar memilih untuk 
tetap melanjutkan usahatani padinya, usahatani padi sudah tidak bisa tetapi disamping itu juga mencari diharapkan, hal tersebut dilakukan karena pekerjaan lain (usaha lain) guna untuk memperoleh tambahan pendapatan dengan jumlah petani sebanyak 14 orang $(45,16 \%)$. Sebanyak 10 orang petani $(32,26 \%)$ lebih memilih tetap melanjutkan usahatani padi sampai masa panen tiba, meskipun produksi padi yang dihasilkannya tidak sesuai dengan yang diharapkan (merugi), hal tersebut dilakukan petani karena tidak mempunyai pilihan lain untuk mereka lakukan. Sebanyak 5 orang petani $(16,13 \%)$ memilih untuk berpindah melakukan usahatani lainnya seperti (sayur-sayuran, umbi-umbian, dll) dengan harapan dapat petani memerlukan pendapatan untuk menghidupi keluarganya meskipun petani harus mengeluarkan modal lebih banyak, dan 2 orang petani $(6,45 \%)$ memilih untuk mencari solusi dengan cara berkonsultasi kepada penyuluh pertanian setempat tentang bagaimana cara mengatasi risiko/permasalahan yang ada, karena mereka berharap tugas dan fungsi penyuluh bisa memberikan jalan keluar agar risiko yang dihadapi bisa teratasi sehingga usahatani padi yang dilakukan tetap berjalan dan bisa menghasilkan pendapatan. Lebih jelasnya dapat dilihat pada Tabel 9.

menghasilkan pendapatan karena

Tabel 9. Strategi Petani dalam Menghadapi Risiko Usahatani Setelah Terjadinya Risiko

\begin{tabular}{clcc}
\hline No & \multicolumn{1}{c}{ Jenis Kegiatan } & $\begin{array}{c}\text { Jumlah } \\
\text { (Orang) }\end{array}$ & $\begin{array}{c}\text { Persentase } \\
\text { (\%) }\end{array}$ \\
\hline 1. & $\begin{array}{l}\text { Tetap melanjutkan usahatani padi sampai masa panen, meskipun produksi } \\
\text { padi tidak sesuai dengan yang diharapkan (merugi). }\end{array}$ & 10 & 32,26 \\
2. $\begin{array}{l}\text { Tetap melanjutkan usahatani padi, disamping itu juga mencari pekerjaan } \\
\text { lain guna untuk memperoleh pendapatan tambahan (usaha lain). }\end{array}$ & 14 & 45,16 \\
3. $\begin{array}{l}\text { Berpindah melakukan usahatani lainnya seperti (sayur-sayuran, umbi- } \\
\text { umbian, dll). }\end{array}$ & 5 & 16,13 \\
4. $\begin{array}{l}\text { Mencari solusi dengan cara berkonsultasi kepada penyuluh pertanian } \\
\text { setempat tentang bagaimana cara mengatasi risiko/permasalahan yang ada. }\end{array}$ & 2 & 6,45 \\
\hline
\end{tabular}

Sumber: Data Primer Diolah (2019)

\section{KESIMPULAN DAN SARAN}

Macam-macam risiko yang dihadapi petani pada usahatani padi pada wilayah bantaran sungai citanduy adalah gangguan organisme pengganggu tanaman (hama, penyakit dan gulma), harga jual gabah/beras yang fluktuatif, lambatnya fasilitas pembangunan (irigasi, jalan, gudang, dll), rusaknya alat-alat produksi akibat penggunaan yang terus menerus, 
dan sulitnya dalam mencari pinjaman modal usahatani. Besarnya risiko berdasarkan nilai CV untuk biaya 0,37 , produksi 0,46 dan pendapatan 0,41 dan semua risiko dikategorikan rendah. Selanjutnya strategi yang dipilih petani dalam mengelola dan menghadapi risiko sebelum mengalami risiko, petani terlebih dahulu membuat perencanaan bersama kelompok tani dan penyuluh pertanian, pada saat masa produksi apabila memasuki musim kemarau, petani lebih banyak untuk memperbaiki saluran air yang ada karena khawatir lahannya kekeringan, dan setelah mengalami risiko, petani tetap melanjutkan usahataninya disamping mencari pekerjaan lain untuk memperoleh pendapatan tambahan.

\section{UCAPAN TERIMA KASIH}

Ucapan terimakasih disampaikan kepada LP2M-PMP Universitas Siliwangi yang telah mendanai penelitian ini, petani padi sebagai responden dan semua pihak yang telah terlibat dalam penelitian ini sehingga terlaksananya penelitian dengan lancar dan menghasilkan sesuatu yang bernilai bagi semua.

\section{DAFTAR PUSTAKA}

Anggani, H. (2005). Analisis Lingkungan Pemanfaatan Bantaran Sungai
Banjir Kanal Timur. Tesis. Program

Pasca Sarjana. Universitas Diponegoro. Semarang.

Badan Pusat Statistik Kota Tasikmalaya, (2015). Kota Tasikmalaya Dalam Angka. Tasikmalaya.

Darmawi, H. (2016). Manajemen Risiko Edisi 2. Jakarta: Bumi Aksara.

Debertin, D.L. (2012). Agricultural Production Economics, Second edition. University of Kentucky. Macmillan Publishing Company.

Goldberg, M. and Palladini, E. (2011). Managing Risk And Creating Value With Microfinance. Jakarta: Salemba Empat.

Miqi, R.H. dan Karyani. (2020). Analisis Risiko Usahatani Cabai Merah Besar (Capsicum annuum L.) di Desa Sukalaksana Kecamatan Banyuresmi Kabupaten Garut. Mimbar Agribisnis, 6(1): 65-76.

Pappas, J.M dan M. Hirschey. 1995. Ekonomi Managerial. Edisi Keenam Jilid II. Bandung. Binarupa Aksara.

Peraturan Pemerintah No. 38 Tahun 2011 Tentang Sungai. Jakarta

Pusat Data dan Sistem Informasi Pertanian. (2016). Outlok Komoditas Pertanian Subsektor Tanaman Pangan. Kementerian Pertanian. Jakarta

Rahim, A. dan Hastuti, D.R.D. (2007). Ekonomika Pertanian (Pengantar, teori dan kasus). Jakarta: Penebar Swadaya.

Robison, L.J. and Barry, P.J. (1987). The Competitive Firm's Response to Risk. New York: Macmillan Publishing Company.

Rofinus, R., Nurliza dan Dolorosa, E. (2016). Analisis Risiko Produksi Usahatani Padi Lahan Basah dan Lahan Kering Di Kabupaten Melawi. Jurnal Social Economic of Agriculture, 5(1): 73-88.

Saputra, R. (2017). Analisis Risiko Usahatani Padi Sawah di Daerah 
Perbukitan desa Kragilan, Kecamatan Gebang, Kabupaten Purworejo. Skripsi. Universitas Muhammadiyah Purworejo.

Shinta, Agustina. 2011. Ilmu Usahatani. Malang: Universitas Brawijaya Press (UB Press).

Soedjana, T.D. (2007). Sistem Usahatani Terintegrasi Tanaman Ternak Sebagai Respons Petani Terhadap Faktor Risiko. Jurnal Litbang Pertanian, 26(2): 82-87.

Soekartawi. (2002). Analisis Usahatani. Jakarta: UI Press.

Sriyadi. (2010). Risiko Produksi dan Keefisienan Relatif Usahatani
Bawang Putih di Kabupaten Karanganyar. Jurnal Pembangunan Pedesaan, 10(2): 69-76.

Sugiyono. (2009). Statistik Untuk Penelitian. Bandung: Alfabeta Bandung.

Suharyanto, Rinaldy, J. dan Arya, N.N. (2015). Analisis Risiko Produksi Usahatani Padi Sawah di Provinsi Bali. Balai Pengkajian Teknologi Pertanian (BPTP) Bali. Jurnal AGRARIS, 1(2): 70-77.

Suratiyah, K. (2015). Ilmu Usahatani, Edisi Revisi. Jakarta: Penebar Swadaya. 